\title{
Northeast Caucasian Language
}

National Cancer Institute

\section{Source}

National Cancer Institute. Northeast Caucasian Language. NCI Thesaurus. Code C161846.

A family of languages spoken in the Russian republics of Dagestan, Chechnya and Ingushetia and in northern Azerbaijan as well as in diaspora populations. 